\title{
Kindergartens in Northern Norway as semiotic landscapes
}

\author{
Anja Maria Pesch,, Maria Dardanou, and Hilde Sollid ${ }^{2}$ \\ ${ }^{1}$ Inland Norway University of Applied Sciences $\mid{ }^{2}$ UiT The Arctic \\ University of Norway
}

\begin{abstract}
Educational institutions have a responsibility to ensure that all children receive care and equal possibilities for development, independent of their linguistic and cultural background. However, there is little knowledge about how kindergartens ensure a welcoming and inspiring place for both transnational migrants, Indigenous children, and children from the majority population. Through a semiotic landscape analysis from two kindergartens in Northern Norway, this article contributes to this knowledge gap. Our starting point is that educational spaces are social, cultural, and political places. Applying a Bakhtinian perspective on semiotic landscapes as dialogues, the analysis focuses on two discourses. The first concerns diversity as an individual or shared value, and the second concerns balancing the ordinary and the exotic. We find that diversity related to transnational migration seems to be more integrated into the semiotic landscape, while the minoritised Indigenous Sámi people is stereotypically represented in kindergartens.
\end{abstract}

Keywords: semiotic landscape, kindergarten, linguistic and cultural diversity, Indigenous Sámi people, dialogues, emic and etic perspectives

\section{Introduction}

As transnational migration and attention on minoritised Indigenous peoples across the world have increased, educational institutions have a responsibility to ensure that all children receive care and equal access to development, independent of their linguistic and cultural background. In particular, early childhood institutions are important for safeguarding all children's experience of belonging, which allows them to thrive and take part in social and pedagogical practices (European Council Communication, 2011; Sadownik, 2018: 956-957). However, there is little knowledge about how kindergartens can ensure a welcoming and

○ Available under the CC BY 4.0 license. ๑ John Benjamins Publishing Company 
inspiring place for all. Based on a semiotic landscape analysis, the current article contributes to this field of research. The empirical point of departure is kindergartens in Northern Norway, where transnational migrants, the historical minorities of the Sámi and Kven/Norwegian Finns ${ }^{1}$ (granted juridical status as Indigenous people and a national minority, respectively) and Norwegians (as the majority) are part of the linguistic and cultural diversity of the region. Even though access to heritage languages and cultures in kindergarten is not given to children with various backgrounds, new immigrants as well as children with Sámi, Kven/Norwegian Finnish and/or Norwegian backgrounds have the right to experience an inspiring and welcoming environment through other semiotic means (Bubikova-Moan, 2017; Øzerk, 2016).

In this paper, the semiotic landscapes of kindergartens are considered an empirical domain where children and pedagogical staff co-construct a place for belonging through both the material aspects of the place (e.g. texts, pictures, toys) and everyday interactions. Thus, our starting point is that a place for belonging for all children - regardless of linguistic and cultural background - includes linguistic and cultural diversity in the semiotic landscape. Our research question is how linguistic and cultural diversity is constructed in the semiotic landscapes of two Northern Norwegian kindergartens. In particular, we ask if diversity is a shared value for all or whether diversity is considered in relation to individual children.

In the following, we first present the societal and educational context of our study. We include a brief outline of Norwegian kindergartens as educational institutions and the national framework plan that provides values and pedagogical directions in kindergartens. Then, we present the theoretical perspectives, before introducing methodological considerations and the data used in the analysis. Finally, we present our findings and concluding remarks.

\section{Societal and educational context}

Increased migration creates increased diversity. According to Statistics Norway (2020a), 18.2\% of the 5,3 million people living in Norway are "immigrants" or "Norwegian-born to immigrant parents", to use Statistic Norway's categories. When transnational migrants settle down in both urban and rural societies, these

1. We use the ethnonym Kven/Norwegian Finns (kvener/norskfinner in Norwegian) as it is used by the Norwegian Ministry of Local Government and Modernisation who is responsible for Sámi and minority affairs in the government. This practice is an attempt to acknowledge the diversity within the group. 
communities become more diverse due to the inclusion of new experiences and perspectives. Some urban areas in Southern Norway - such as Oslo, where 33,1\% of the total population are immigrants or Norwegian-born to immigrant parents may be best described as superdiverse, to use Vertovek's (2007) term. Although this phenomenon occurs on a smaller scale in Northern Norway, where the data for this study were collected, diversification of diversity is a valid description of urban areas in this region. In the largest city, Tromsø, at the beginning of 2019, $14.7 \%$ of the population were immigrants or Norwegian-born to immigrant families (Kommuneprofilen, 2019) and around 130 different languages are spoken. Other, more rural municipalities can have an equal or larger proportion of immigrants. For example, the municipality of Skjervøy, which is located north-east of Tromsø, has 2917 inhabitants (Kommuneprofilen, 2019). Of these, 15,3\% are migrants from 29 different countries, with the largest group (42\%) hailing from Romania.

Even though superdivesity is a recent phenomenon in Northern Norway, linguistic and cultural diversity is not (e.g. Brochmann \& Kjeldstadli, 2014; Pietikäinen, Huss, Laihiala-Kankainen, Aikio-Puoskari \& Lane, 2010). The Sámi are recognised as Indigenous people, and Norway has recognised five other historical minorities (Kven/Norwegian Finns, Forrest Finns, Jews, Roma, and Romani people/Tater $)^{2}$ as national minorities on the basis of their long history in Norway. Both the Sámi and the national minorities were minoritised as a result of Norway's colonial policies. The process of colonisation was an internal colonialism with the aim to regulate people and their religious, cultural, and linguistic practices in order to promote a Norwegian identity and belonging. The Norwegianisation policy was abandoned after World War 2, but we can still observe long-term consequences, like language shifts and marginalisation. Today, at the national level, the state supports processes of revitalisation and reclamation of minoritised languages and cultures. Kindergartens play an important role in these processes (Olsen \& Andreassen, 2016).

The Norwegian education system is centralised, and by basing their daily activities on both national policy regulations and local surroundings, kindergartens negotiate and recontextualise the national educational policies outlined in policy documents, helping to create awareness of historical minorities at a national level. While the educational sector was a main arena for the Norwegianisation policy, there has been a paradigm shift as the education system today

2. The Norwegian ethnonyms are kvener/norskfinner, skogfinner, jøder, roma, and romani/ tatere. One of the main differences between Kven/Norwegian Finns and Forrest Finns, is the traditional homeland, with Kven/Norwegian Finns in the North and Forrest Finns in the South Eastern parts of Norway. 
is an important arena for supporting revitalisation of Norway's three Sámi languages (South, Lule, and North Sámi) and Kven/Norwegian Finnish (the latter only in Troms and Finnmark county). Indeed, there is an ongoing process of indigenisation of education in Norway (Sollid \& Olsen, 2019). This means that there are separate Sámi kindergartens and also kindergartens with co-located Sámi and Norwegian sections. In addition, as outlined by the national curricula, all kindergartens are expected to provide knowledge about Sámi culture and society and, in so doing, develop an inclusive community based on reciprocal respect (Norwegian Directorate for Education and Training, 2017).

In Norway, kindergarten is attended by children aged 1-5 years. It is not mandatory, but $92,2 \%$ of children within this age group attend kindergarten (Statistics Norway, 2020b). The pedagogical work is based on a national framework plan for the content and tasks of kindergartens, which is a regulation outlined in the Kindergarten Act. A new framework plan went into force in 2017 (Norwegian Directorate for Education and Training, 2017). However, in this article, we will refer to the 2011 Norwegian framework plan for the content and tasks of kindergartens (Kunnskapsdepartementet, 2011), which was in use during the period in which data for this article were collected.

The 2011 framework plan (Kunnskapsdepartementet, 2011) focuses on human equality, solidarity, freedom of thought, compassion, and forgiveness. The purposes, values, and tasks of the kindergarten are based on children's development, play, activity, learning, formation, and participation, and they focus on holistic development of the child. Although the framework plan does not specifically refer to the theoretical background on which it is based, its relation to sociocultural theory is obvious. For example, Vygotsky highlighted the role of language in general and one's mother tongue in particular for interaction, language development and participation (Øzerk, 2016). His theory also emphasises the connection between language and cognition, reasoning and reflection (Vygotsky, 1986; Wittek, 2014). Play and interaction with others are also considered important parts of children's language development, as there is a connection between the importance of language acquisition and social communication for the development of children's mental processes (Karpov, 2005). Likewise, the plan refers to the importance of language as a means of communication and a tool for reasoning and expressing thoughts and emotions (Kunnskapsdepartementet, 2011).

On the one hand, the framework plan requires kindergartens to support the use of a 'mother tongue' among 'children with a mother tongue other than Norwegian' and actively develop children's 'competency in Norwegian' (Kunnskapsdepartementet, 2011:35). On the other hand, the Kindergarten Act (Barnehageloven, 2005) emphasises that kindergartens must take into consideration children's social, ethnic, and cultural background. Nevertheless, according 
to Bubikova-Moan (2017), there is a dichotomy between being multilingual and being Norwegian in official policy documents. The framework plan refers mainly to multilingual children as children for whom Norwegian is a second language, which contributes to the dichotomy.

Based on the outline of the context, there is a need for further analysis of the discursive relationships between the concepts of 'Norwegian', 'Sámi', and 'multilingual' in kindergarten settings. Our study contributes to this knowledge need at the level of kindergarten practices.

\section{Theoretical background}

The starting point for our analysis is that physical spaces, like kindergartens in Northern Norway, are also social, cultural, and political places. As such, the semiotic landscapes of educational places are not neutral, and as Blommaert (2013:3) points out, a space is always somebody's place. These semiotic landscapes, or schoolscapes, are sites 'where place, text, and other semiotic resources constitute, reproduce and transform' ideas of whose place this is (Brown, 2012:282). As the term 'schoolscape' may imply, research into schoolscapes has mainly been carried out within school contexts (e.g. Laihonen \& Szabó, 2017; Sollid, 2019; Szabó, 2015). At times, 'linguistic landscape' is used as an equivalent term (e.g. Garvin \& Eisenhower, 2017; Gorter, 2006; Pakarinen \& Björklund, 2017). It is worth considering whether the term covers the semiotic landscapes of kindergartens in the context of Norway. Even though kindergartens can be educational spaces, they differ from schools in their curriculum, pedagogical aim, and approach. An example of this is aims formulated in the curricula. The school curriculum states competence aims for students, while the kindergarten framework plan outlines guidelines and aims for the staff. Jaworski and Thurlow (2010) argue that the term 'semiotic landscape' covers ways that linguistic discourses and other discursive modalities, such as pictures and nonverbal communication, can interact. It also covers the possibility of semiotic resources other than language, which is why we have chosen the term 'semiotic landscape' for this paper.

In our analysis, we focus on how ideas of linguistic and cultural diversity are created in and through the semiotic landscape. In particular, we are interested in how linguistic and cultural diversity are part of creating belonging in the context of kindergartens. We see ideas of belonging from a language ideological point of view, as a conceptualisation of the relationship between speakers, languages and discursive practices (Irvine \& Gal, 200o). Part of the semiotic landscape framework is the concept of discourse. We base our understanding of discourse on the nexus analysis framework (cf. Scollon \& Scollon 2004:2), where discourse 
both refers to the use of language in social interaction and the use of language to accomplish action in the social world. As such, this notion of discourse integrates both micro and macro level perspectives on social action. This approach to discourse suggests that the semiotic landscape is language use in interaction and that the semiotic landscape is intended to achieve something within the educational space. Moreover, discourses found in the kindergartens connect to discourses on an overall level, for example in steering documents or teacher education. Seeing the semiotic landscape as social action, we recognise that there are numerous circulating discourses, some more relevant than others, depending on the viewpoint of the participant and their motives (Scollon \& Scollon, 2004: 11). For our purposes we focus on discourses in place that concern our research question, namely diversity and belonging.

As mentioned earlier, the Norwegian education system is centralised, and due to social and political stability, it has been fairly stable for many years, as the pedagogical foundation has not changed. However, this is not to say that ideas of belonging are stable or uniform. As Brown (2012) and Laihonen and Tódor (2015) show, the schoolscape can change as social and political circumstances change. In the Norwegian context, the political recognition of the historical minorities as well as increased transnational migration is changing the circumstances of pedagogical practice. Also, the semiotic landscape can change as a consequence of local institutional developmental work, as all kindergartens are required to be learning organisations by the framework plan. Following Brown (2012), semiotic landscapes project ideas and messages about what is officially accepted or sanctioned at a particular institution. This includes educational aims and ideals, which may be culturally embedded (see Garvin \& Eisenhower, 2017; Szabó, 2015). As Brown (2012) points out, material spaces project ideas about what and who is sanctioned and supported through semiotic resources in the educational context. Kindergartens create environments where the material dimensions contribute to negotiations about what and who is valued in this institution, both through the choice of artefacts presented and through the way they are displayed.

Although research about linguistic landscapes within the education sector is increasing (Laihonen \& Szabó, 2017, 2018), there are still few studies on semiotic landscapes in kindergartens. In her study of the semiotic landscapes of two kindergartens, Pesch (2017) found that linguistic diversity emerges as both a value attached to individual children and as a value shared by all children, regardless of their linguistic background. In addition, in their study of a North Sámi language nest kindergarten in Finland, Pachné Heltai and Bartha (2017) found that signs in North Sámi were placed on top of signs in Finnish for the Sámi group of the kindergarten, indicating that the minority language was valued. They also highlight the fact that rooms equipped with traditional Sámi artefacts were viewed as 
historical (belonging to the past), authentic or exotic, depending on the groups of actors who used them and the visual construction of being Sámi within the city's community. The fact that different actors may have different views on semiotic landscapes is emphasised by Laihonen and Szabó (2017), Szabó (2015) and Szabó and Troyer (2017) and is used as an argument for combining different methods of semiotic landscape research that include both the researchers' and participants' perspectives.

In semiotic landscapes, there are numerous discourses that may contribute to our understanding of diversity. Here, we focus on belonging in linguistically and culturally diverse kindergartens. To operationalise ideas of belonging, we investigate how the semiotic landscape achieves intercultural relationships and competence. We base our understanding on the work of Barret, Byram, Lázár, Mompoint-Gaillard, and Philippou (2014) and Østberg (2017), who emphasise a dialogic stance as the starting point for developing intercultural competence. Barret et al. (2014) describe intercultural competence as a combination of attitudes, knowledge, understandings and skills applied through action. Through their actions, participants are enabled to:

understand and respect people who are perceived to have different cultural affiliations from oneself, respond appropriately, effectively and respectfully when interacting and communicating [...], establish positive and constructive relationships [...], understand oneself and one's own multiple cultural affiliations through encounters with cultural 'difference'.

(Barret et al., 2014:16 f.)

A question that arises is whether a semiotic landscape actually does achieve intercultural competence. Potentially the landscape erases (parts of) diversity, and it may position participants in various ways. Thus, a semiotic landscape may also point to exotification and othering (cf. Coupland 2010), creating a sense of 'we vs. them'

To elaborate on semiotic landscapes as part of a dialogue, we draw upon Bakhtin. From a Bakhtinian perspective, semiotic landscapes are dialogues that are filled with utterances. Bakhtin (1986) views the utterance as the fundamental linguistic entity. Every utterance has specific content, is filled with the speaker's intention, is related to a context, and is addressed to another speaker or group of speakers. In other words, utterances position participants in the dialogue and convey the speaker's ideology. Ideology is not understood as a normative concept, nor necessarily as a political concept (Freedman \& Ball, 2004; Ongstad, 2004). Ideologies create meaning because they are part of the exchange of semiotic signs (Bakhtin, 1986). Thus, ideology is connected to a worldview that is inherent in every semiotic system (Ongstad, 2004) as well as to the worldview of individuals or groups of people. Moreover, ideology is dynamic. People develop 
their ideologies by struggling with others' ideologies (Freedman \& Ball, 2004). Even though Bakhtin's concept of ideology is not necessarily political, it may be politically oriented systems of ideas (Freedman \& Ball, 2004). In similar vein, Irvine (1989:255) sees language ideologies as "cultural (or subcultural) system of ideas about social and linguistic relationships, together with their loading of moral and political interests - which is a crucial mediating factor".

Utterances are dialogic; they always relate and respond to previous utterances and involve different understandings (Bakhtin, 1986). Moreover, utterances anticipate prospective utterances in the future (Silseth, 2014). This principle of dialogicity (Silseth, 2014), which views a single utterance as a rejoinder in a chain of utterances, is an interesting aspect of the analysis of our data material. When the resources in the kindergartens' semiotic landscapes are viewed as utterances, these utterances are dialogically filled with views on belonging and cultural and linguistic diversity. Therefore, the utterances we find in the kindergartens' semiotic landscapes may confirm or challenge previous utterances on cultural and linguistic diversity in national curriculum and policy documents, and they might relate to utterances that are common in the local and regional context. Simultaneously, they convey the kindergarten's intentions and anticipation regarding further utterances of possible addressees, as children and parents. In this respect, the semiotic landscapes are constructions of cultural and linguistic diversity in a single kindergarten on the one hand and, on a broader local, regional, and national level on the other hand. Thus, semiotic landscapes are part of a dialogue on the constructions of belonging and cultural and linguistic diversity on different scales of time and space (Hult, 2017).

To explore the interrelationship between time and space in the analysis of semiotic landscapes we draw upon the chronotope, a concept that has already been applied in research on linguistic landscapes (Pietikäinen, 2014). The chronotope "expresses the inseparability of space and time" and combines spatial and temporal elements into a "concrete whole" (Bakhtin, 1981: 84). It emphasizes that action, though carried out in a certain place and at a certain time, always relates to past and future discourses, making it impossible to understand the message without knowing the history (de Vocht, 2015: 66, see also Scollon \& Scollon 2004). Thus, the chronotope may be interpreted as a parallel to the nexus of practice in nexus analysis (Pietikäinen, 2014:481; Pesch, 2017:101-102). In the analysis of the kindergartens' semiotic landscape, the chronotope emphasises the importance of diachronic perspectives of the space on different time scales as part of the semiotic resources studied. 


\section{Methodology: Research methods and data analysis}

The data presented in this paper were collected as part of a research and development project on linguistic and cultural diversity during the winter and spring of 2015. The diversity project was part of a national project called Kompetanse for mangfold (Competence for Diversity). In line with the project guidelines (Lødding, 2015; Utdanningsdirektoratet, 2017), the focus was on 'new' diversity, but there was also an interest in the diversity represented by Sámi and Kven/Norwegian Finns. The data collection was inspired by Blackledge and Creese (2010), where a team of researchers collaborated to complete a multi-site ethnographic project. As part of Kompetanse for mangfold, a research team collaborated to collect snapshots from a number of educational institutions (both kindergartens and schools) during the same time of the year. The data material is comprised of 27 educational institutions and includes interviews with the teachers and leaders of the institutions, photographs from different rooms, field notes after the interviews and documents like plans and informational brochures. Due to the national frame of the project where we as teacher educators were to focus on the pedagogical staff, we did not include children or parents in our data. Also, the timeframe was strict. For the interviews, an interview guide that could be adapted to the individual interviews' settings was developed. The interviews were based on the walking tour methodology (Garvin, 2010) and, more specifically, on the tourist guide technique (Szabó, 2015). The Norwegian Data Protection Service (NSD) approved the project.

In the research team, the authors had different roles. The diversity project was situated within teacher education, where we all work. As teacher educators, we are familiar with foregrounded discourses on multilingualism, multiculturalism, and language learning in the education sector. While all three authors contributed to the data collection, Sollid also was the leader of the diversity project. The data in this article, were collected by Dardanou and Pesch, but analyzed by all three authors. We are part of the northern diversity. Dardanou and Pesch are transnational migrants, who have moved to Norway and consider themselves multilingual. Sollid is from a historically trilingual area, but due to Norwegianisation politics she grew up with speaking Norwegian only. She considers herself Norwegian and Sámi.

In our analysis, we use the findings from two kindergartens, here referred to as Mountain and Moon Kindergarten. The data include 5.5 hours of interviews with two kindergarten leaders and four kindergarten teachers as well as 74 photographs from the two kindergartens and 6 documents (annual and developmental plans and interviewers' field notes). The data is collected in collaboration with the participants as they guided us through the kindergartens. This means that 
they contributed to deciding what was relevant or important for the research project. Given this, we acknowledge that there might be semiotic resources, and hence ideas of belonging that might have escaped our attention. From a research ethical perspective, the collaborative approach is important. We only spent about a couple of hours in the kindergartens, and rather than being guided by our own preferences and previous knowledge, we wanted to make space for the emic perspectives of our participants. While the researchers decided that the semiotic landscape was the main focus, the participants decided what in the landscape that they wanted to show us. In our analysis we view it as equally important to critically discuss the semiotic landscape with our perspectives as researchers, as to point to the teachers' emic perspectives.

The discourse analysis is based on interpretation of photographs and interviews (Scollon \& Scollon, 2004; Szabó, 2015; Øierud, 2011). In our analysis, we pay attention to different elements in the photographs of the semiotic landscapes (e.g. toys, texts, clothes, furniture, colours, placement) and the affordances of the semiotic signs according to the participants in the walking tour interviews. These interviews revealed that the semiotic landscape have different affordances for the researchers and participating kindergarten teachers and leaders (Tønnesen, 2010), and the procedure of the analysis is designed to consider these differences. First, we analysed photographs of the different rooms of the kindergartens that the participants showed us and asked ourselves, What do we see?. Thereafter we reanalysed the photographs by looking for what the kindergarten staff told us about elements of the semiotic landscapes during the guided tours. Here, the participants' emic perspectives and motives (Scollon \& Scollon, 2004) is an important element in identifying the foregrounded discourses. This procedure acknowledges that researchers, as outsiders, and kindergarten staff, as insiders, might interpret elements of the semiotic landscapes differently. One of the limitations with the guided tour method is that what initially seem to be details, might require more questions to the kindergarten staff. Therefore, to acknowledge the data collection procedures in the analysis below, we carefully report on the participants' and our perspectives, and engage more critically in the findings in the discussion.

In the data there are numerous discourses on diversity and belonging that are potentially interesting, but we chose two that are foregrounded in the nexus of practice from emic perspectives and also relevant in light of the framework plan and previous research. The analysis was abductive, going back and forth between the theoretical framework and data. The first discourse, 'diversity as a shared or individual value, was presented in previous research conducted in the same context (e.g. Pesch, 2017), and it resonates with the discourses in policy documents (Bubikova-Moan, 2017). We explore this discourse further in new data. The second discourse is 'balancing the ordinary and the exotic'. An utterance in one of 
the interviews explicitly related to this discourse, and even if there is only one utterance, it connects to the wider theoretical discourse on linguistic and cultural diversity, including processes of 'intercultural competence' (Barret et al., 2014) and 'othering' (Coupland, 2010).

From an epistemological perspective, semiotic landscapes are changing from day to day (cf. Gorter, 2006), but the main method of documentation is the creation of frozen representations of the landscape (i.e. taking photographs and doing interviews at a fixed point in a flow of social action and change). In order to resolve this possible tension, we argue, in line with Blommaert (2013), that it is necessary to go beyond simply noticing differences in the perceptions of semiotic signs. We aim to integrate different perceptions and interpret them as complex discourses of belonging in a setting with cultural and linguistic diversity. Through this approach, we recognise that both the interviewee and interviewer contribute to knowledge production (Kvale \& Brinkmann, 2017). While researchers typically have a synchronic perspective on place that is informed by research knowledge from other settings, the kindergarten staff have insight on the historical trajectories and long-term experiences of the kindergarten. Given that educational practices are more complex and dynamic than can be shown by semiotic signs, we, as researchers, find this combination of analysis approaches important, as it provides us opportunities to gain more insight into the recursivity of ideas regarding language and culture in education and educational practices.

\section{Findings}

In the following, we focus on the two discourses mentioned above: 'diversity as a shared or individual value' and 'balancing the ordinary and the exotic'. In this section, we use photographs and excerpts from the data that explicitly show these discourses.

\subsection{Diversity as a shared or individual value}

At an overall level, our data show that linguistic and cultural diversity is, to some extent, expressed as a shared value in the semiotic landscape, but this is not a permeable practice in kindergartens. Prominent semiotic resource used to express diversity in Norway are national flags (cf. Pesch, 2017; Sollid, 2019). These flags are intended to represent all children's national backgrounds. The Sámi flag is also included in Mountain Kindergarten (Figure 1), even though, according to our data, none of the children or teachers had a Sámi background. This practice seems to connect to the idea that one child is representative of one nation. However, a 
closer examination reveals other semiotic resources in which all children's linguistic and cultural backgrounds are represented. One example, also from Mountain Kindergarten, is a poster with red and blue painted hands (we assume that the colours is a binary representation of girls and boys) and the word 'welcome' in the languages represented in the group of children (Figure 2). Sámi is not present. We interpret this difference between the flags and the welcome poster as a difference between officialness (flags) and localness (the actual children in the group). Both the flags and hands are placed in the entrance area, visible to children and parents as they arrive or leave. This placement contributes to the identification of the kindergarten based on the diversity of the group.

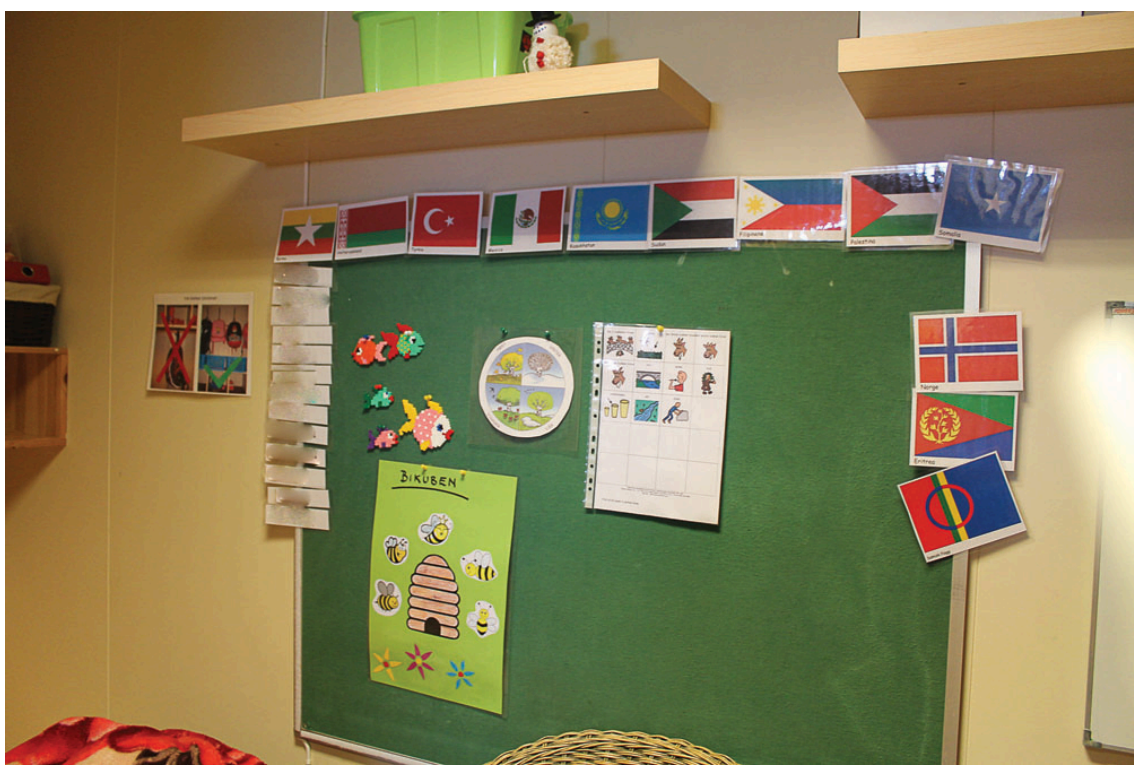

Figure 1. Flags (Mountain Kindergarten)

According to the kindergarten staff, both the flags and languages on the welcome poster were chosen based on collaboration with the parents. This ensures that the child (and the parents) are represented by their preferred national symbol and name for the country from which they came. One teacher at Mountain Kindergarten stated that this is the reason why they chose to write Burma and not Myanmar, the official name of the country. From a Bakhtinian perspective, this choice is based on former utterances that precede the composition of the semiotic resource. The flags and welcome poster can thus be read as a response in an ongoing dialogue (Bakhtin, 1986) that includes the parents and their views and ideologies. Interestingly, this dialogue includes both the individual child and fam- 


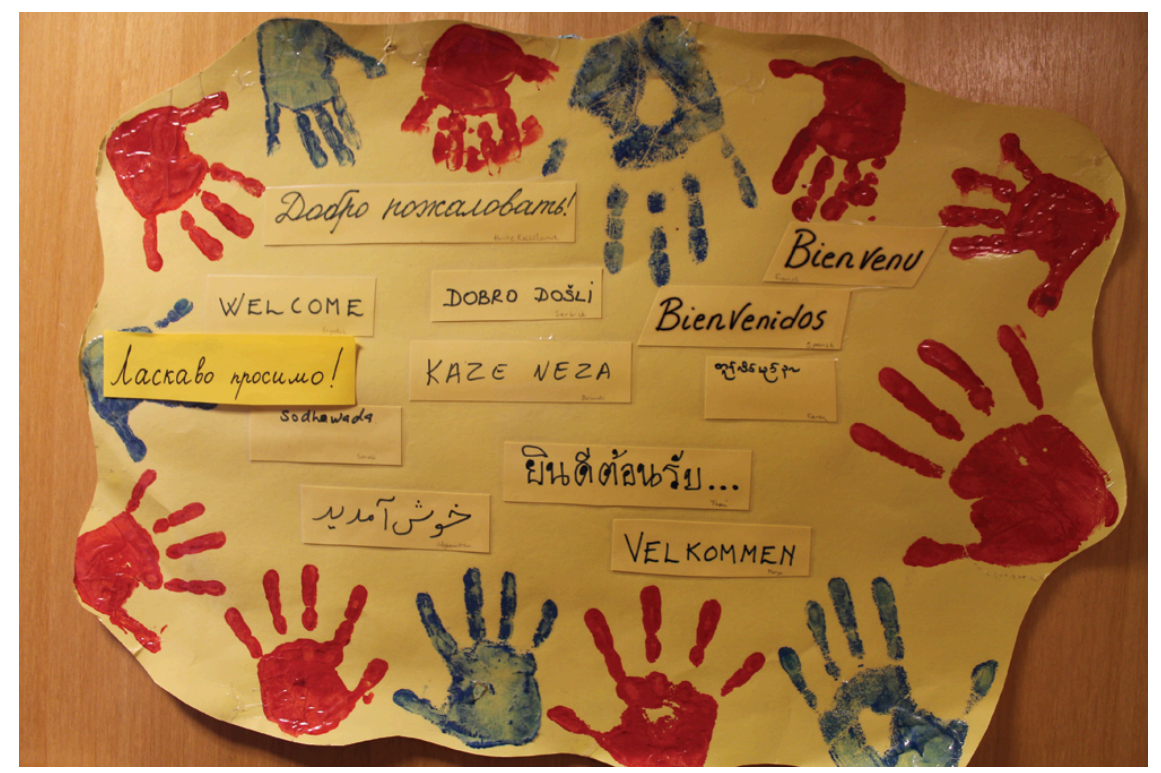

Figure 2. Welcome poster (Mountain Kindergarten)

ily and shared experiences of the kindergarten group. The choice of flags and the welcome poster point backward in time and space, and they create a new chronotope for individual children and families and for the group of children, which also points to the future. Together, the flags and welcome poster are symbolic representations of the diversity of Norway and the diversity of backgrounds in the kindergarten. They promote an integrated view of diversity that represents all children and adults as a collective 'we'. Drawing upon Brown (2012), Szabó (2015) and Garvin and Eisenhower (2017), this gives an impression of individual and shared diversity as desired, accepted, and valued in the kindergarten.

The kindergarten teachers state that the parents do not necessarily ask the kindergarten to display the flags, but they like it when it is done. We believe this relates to positive attitudes towards flags as national symbols, which are quite common in Norwegian kindergartens and schools. It might also reveal a difference in the parents' and kindergarten's expectations regarding the representation of diversity in Norwegian kindergartens. Drawing on the idea of belonging as a conceptualisation of the relationship between speakers, languages, and discursive practices (Irvine \& Gal, 2000), we argue that the flags on the one hand support an idea of one child, one nation, and on the other hand together the welcome poster are part of discursive practices intended to create diversity as a shared value.

Looking at semiotic resources that are closer to everyday pedagogical work, we can identify diversity practices that are more directed towards the individual 
child rather than the whole group. One example is a Russian-Norwegian booklet from Moon Kindergarten, which was made by the kindergarten staff for a child with a Russian-language background in cooperation with the parents (Figure 3). The booklet includes pictures of food and everyday items needed in the kindergarten with names written in both Norwegian and Russian. Additionally, a translation of the word from the Cyrillic to the Latin alphabet, makes it readable for the kindergarten teachers. According to the kindergarten teacher, the booklet was placed on the child's wardrobe where it could be accessible to the child, and it was used by the teachers to help the child learn Norwegian words faster and communicate easier. Our data does not state whether the booklet also was used on initiative of the child. This practice relates to the requirement in the framework plan to actively support the development of multilingual children's linguistic skills in Norwegian (Kunnskapsdepartementet, 2011). Additionally, it can be interpreted as a part of the socio-cultural pedagogical background on which the Norwegian framework is based, which emphasises children's interactions with both other children and the teacher as important for language learning (Karpov, 2005). Alternatively, the booklet can be understood as a response to former utterances in a dialogue between kindergarten teachers and parents (Bakhtin, 1986). Upon closer examination, one can see that the Norwegian word is given the prominent position in the booklet. For example, one of the pictures displays bread with a topping, which is a typical breakfast and lunch in Norwegian kindergartens. The word written next to the slice of bread is mat ('food'), which can be interpreted as a simplification and an implicit Norwegian ideology and educational aim (Brown, 2012) of the correct food to bring to kindergarten. Other pages in the booklet depict items that are often used in kindergarten, such as winter clothes, a toilet, and items for play. In line with Brown (2012), Garvin (2010) and Szabó (2015), we argue that this booklet is connected to Norwegian values, which are embedded and taken for granted as a baseline for linguistic and educational goals in Norwegian kindergartens.

The booklet, as an utterance, positions both the kindergarten and the individual child in a dialogic relationship on learning Norwegian (Bakhtin, 1986). It is a tailored, individual resource, and it represents the idea of adapted education. It builds on a sense of belonging that goes beyond celebrating different cultural and linguistic backgrounds; it is connected and implemented in kindergartens' daily practices of diversity as individual language learning of Norwegian. It creates a chronotope, a space intertwining the child's past as mainly Russian speaking with enhancing Norwegian as an important future language.

The intentions underlying the booklet are in accordance with the kindergarten framework plan. In addition, the booklet affords the possibility for all children and adults to learn some Russian words. Still, according to the kindergarten 


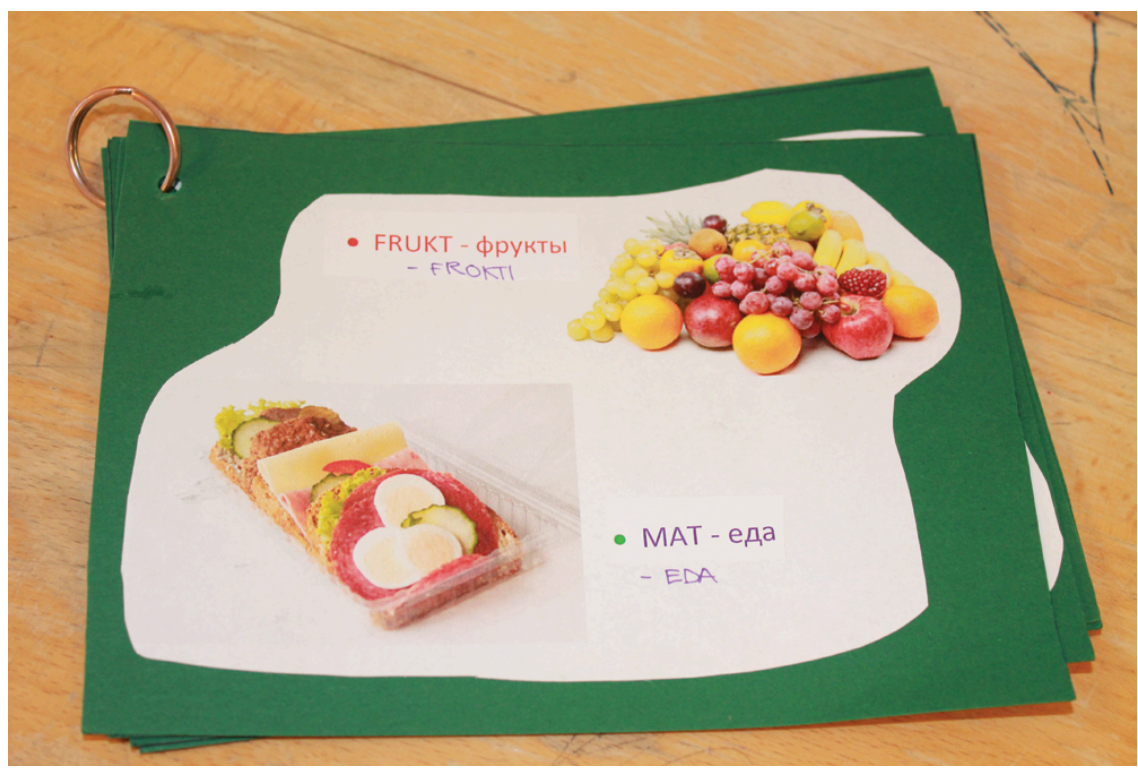

Figure 3. Russian-Norwegian booklet (Moon Kindergarten)

staff it is mainly used to facilitate the Norwegian skills of one individual child. Thus, the booklet, as a semiotic resource, does not exclusively contribute to a discourse of belonging but also contributes to difference and othering (Coupland, 2010:244). The relational dimension of intercultural competence (Barret et al., 2014), which could be applicable to this situation, seems to be replaced with instruction about Norwegian culture and values. Therefore, this example raises a question about standardisation: what is typical in Norway, and thus, what does the child need to learn?

Another semiotic resource that raises questions about whether diversity is a shared or individual value is a strategy plan for resolving conflicts in Moon Kindergarten (Figures $4 \mathrm{a}$ and $4 \mathrm{~b}$ ). In the interviews, the kindergarten teacher explained that the plan was made with children's participation and was kept in the group room where it was easily accessible to children. The teacher emphasised how its use helped to solve conflicts and strengthen children's friendship, and that the plan could be used with both Norwegian and multilingual children because the latter children could look at the pictures if they did not understand. Based on this, it seems that visualisation is reserved for multilingual children, while Norwegian children are considered to be competent readers. Although some children are able to read before they leave kindergarten and go to school, this is not normally the case in Norway. Indeed, all children's literacy is based on their ability to read pictures. An implicit idea in the kindergarten teacher's statement is that 
the pictures can support children's oral use of Norwegian. However, the pictures do not display the same content as the text, and only reading the pictures to find the intended meaning of the text as a whole without support from others, might be difficult for the child. Nevertheless, the conflict-solving plan connects to a discourse regarding pedagogical practices related to multilingual children that promote the use of objects and pictures to achieve better understanding and use of the Norwegian language. The Russian-Norwegian booklet uses a similar practice (i.e. using pictures to concretise culture-specific concepts).

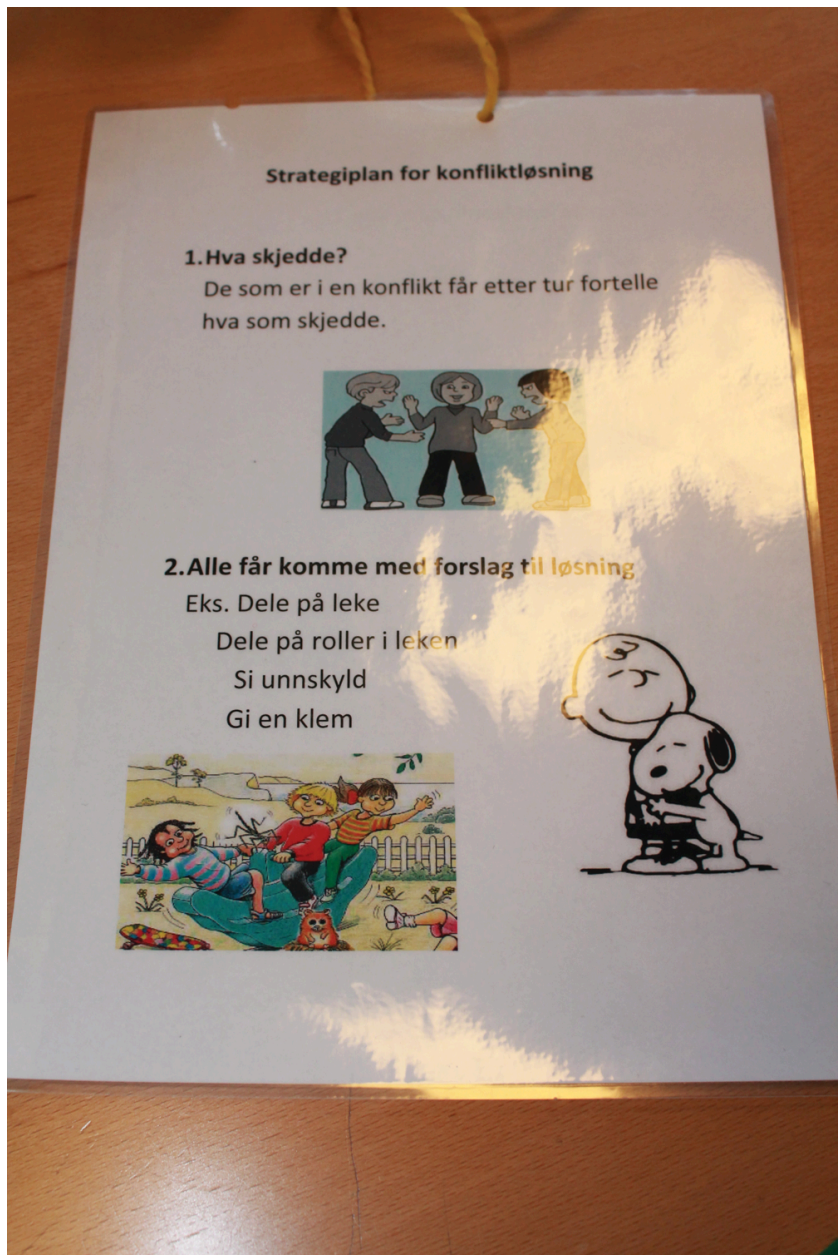

Figure 4a. Strategy for solving conflicts (Moon Kindergarten)

To summarise, the semiotic landscapes of the kindergartens show the intentions of the staff to visualise the linguistic and cultural resources of the group 


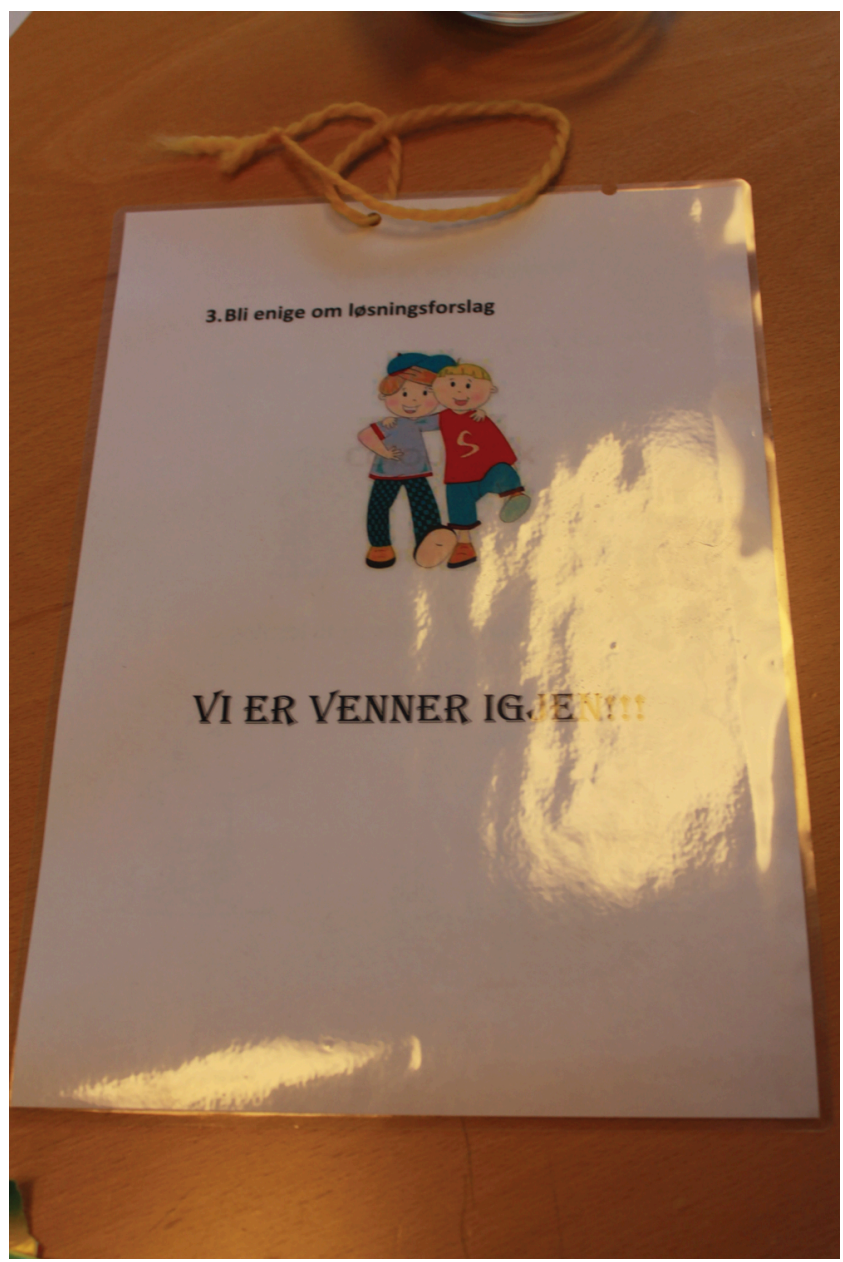

Figure 4 b. Strategy for solving conflicts (Moon Kindergarten)

to foster a sense of belonging, either through shared values represented by the flags and welcome poster or through individual resources intended to support individual children's learning of Norwegian. Drawing on the principle of dialogicity (Silseth, 2014), these practices limit and standardise future utterances. As a consequence, the semiotic landscape conveys an understanding of legitimate actions and practices to all children, including ideas of belonging. A question that arises is whether the practices provide opportunities for more/other stories, more/other voices or more/other perspectives to be taken into consideration and pedagogically practised in relation to children's linguistic and cultural background (Bakhtin, 1986; Pachné Heltai \& Bartha, 2017). 


\subsection{Balancing the ordinary and the exotic}

The data used for this article were collected around February 6, which is the Sámi National Day. For the kindergartens, this may be a good time to address Sámi topics, and for researchers, it is a good time to find an access point to explore the conceptualisation of the role of Sámi culture in relation to the wider concept of diversity in the kindergartens. According to the framework plan (Kunnskapsdepartementet, 2011), Norwegian kindergartens must improve all children's knowledge about the Sámi as Indigenous people. Specifically, kindergartens should ensure that children have knowledge about Sámi culture and everyday life.

According to our data, the kindergartens mainly display cultural semiotic resources, and written texts in any of the Sámi languages are hardly present in the semiotic landscape. The only exception is numbers written in North Sámi (from 1 to 10 in Moon Kindergarten, Figure 5; from 1 to 5 in Mountain Kindergarten, Figure 6). As shown in Figure 5, in Moon Kindergarten, the numbers are listed on a A4 poster and accompanied by pictures of the Sámi flag and details of Sámi traditional clothing (gákti in North Sámi). Interestingly, as shown in Figure 6, Sámi is one of 13 languages present at Mountain Kindergarten, and it is on equal footing with the other languages. For this reason, similar to the flags shown in Figure 1, we interpret Figure 6 as expressing that diversity is both an individual and shared value and both an expression of officialness (Sámi languages) and localness (the languages of the children in the group).

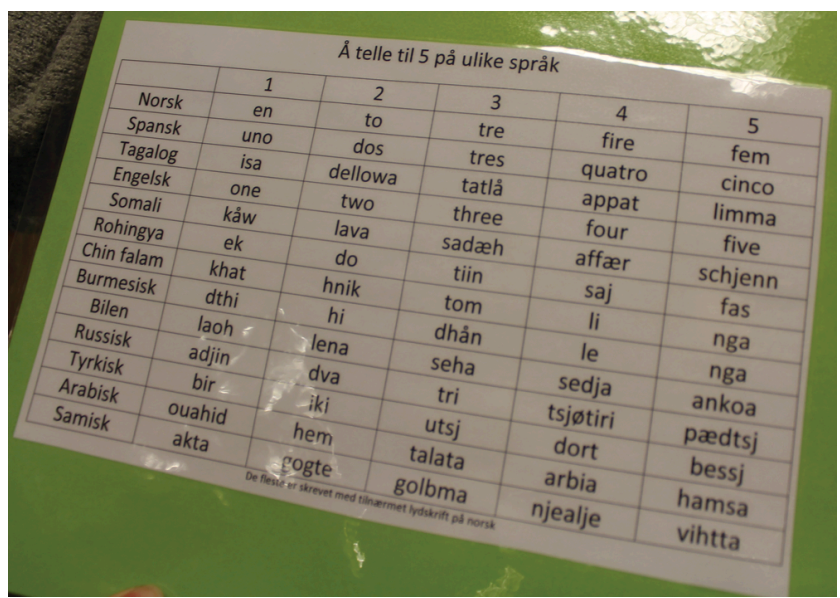

Figure 6. Counting to 5 in 13 languages (Mountain Kindergarten) 


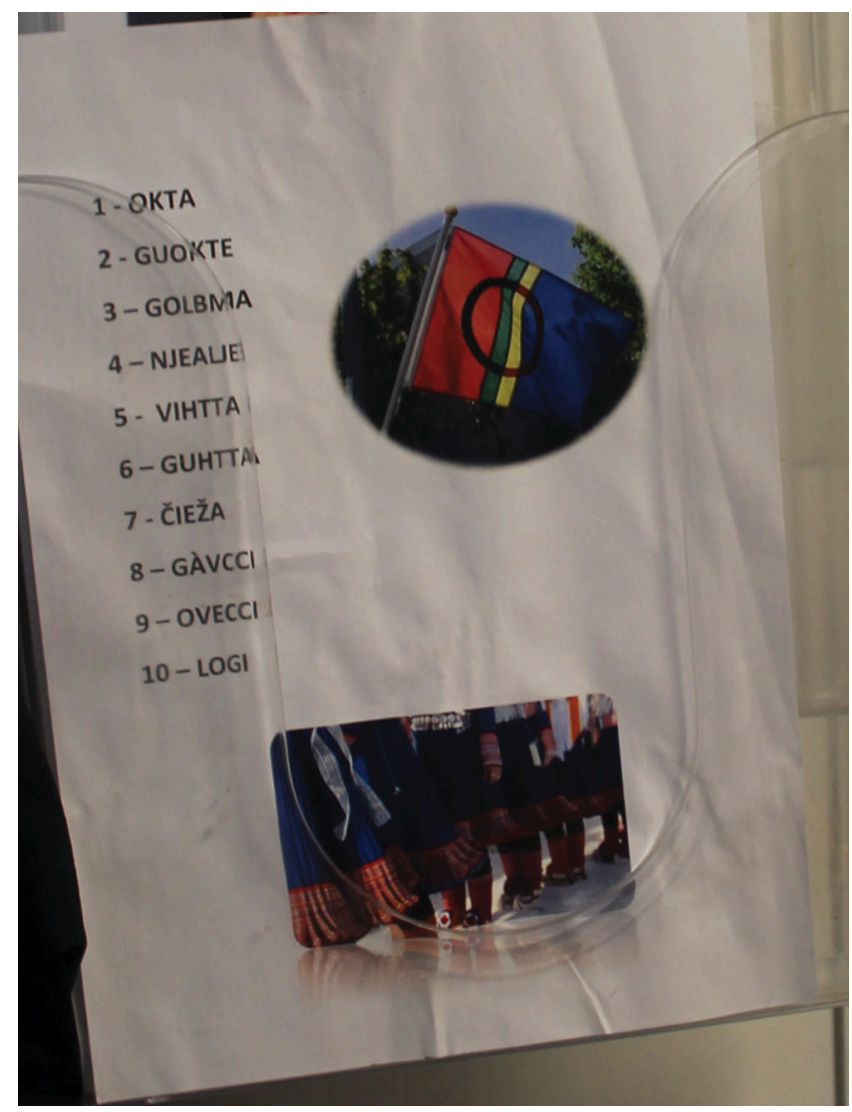

Figure 5. From 1 to 10 in North Sámi (Moon Kindergarten)

An emphasis on culture in the semiotic landscape reflects the priorities in the framework plan; the cultural dimension is explicit, while languages are not mentioned. Closer examination of the cultural dimension of the data reveals that the semiotic resources connected to the Sámi are mainly national symbols, like the Sámi flag and the gákti. In Figure 7, which depicts Moon Kindergarten, one can see the Sámi flag placed on top of the microwave and, next to it, several pictures showing Sámi gákti. Activities related to reindeer husbandry, a traditional livelihood in Sápmi, are depicted. Figure 8 shows two Sámi winter coats (beaska in North Sámi) that were placed on the wall in the hallway of Mountain Kindergarten.

According to the interviews, the flag and pictures displayed in Figure 7 are related to the celebration of the Sámi National Day. The prominence of traditional Sámi resources is suitable for the festive occasion, and they are part of the process of cultural differentiation (Irvine \& Gal, 200o) between the Sámi and Norwegian 


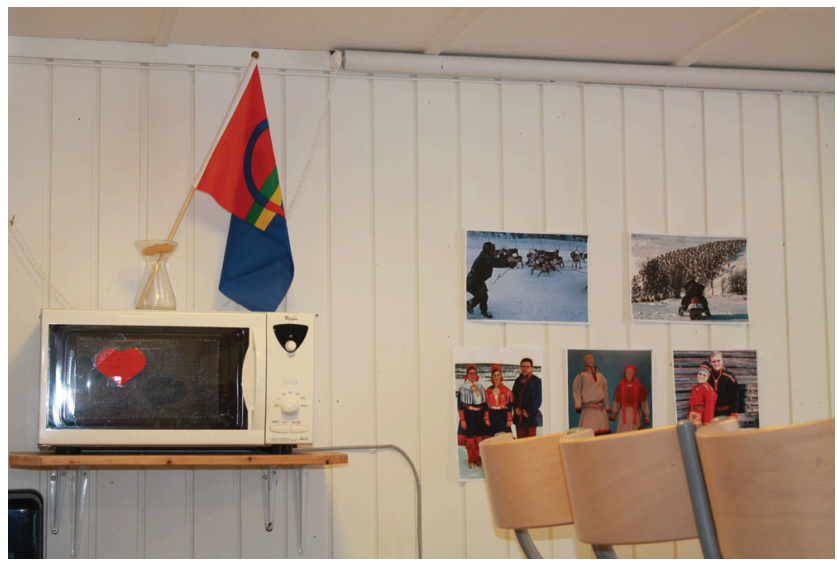

Figure 7. Celebration of Sámi National Day (Moon Kindergarten)

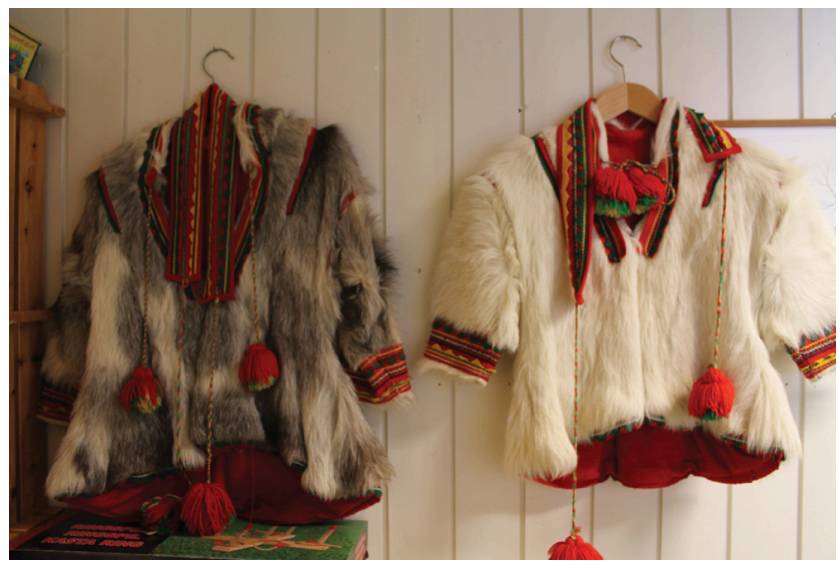

Figure 8. Sámi coats in the hall (Mountain Kindergarten)

cultures. Together with the words for numbers (Figure 5 and 6) and the flags (Figure 1), the traditional clothing describes the Sámi as part of the linguistic and cultural diversity of these kindergartens. However, the absence of everyday cultural or linguistic items beyond numbers might contribute to exotifying the Sámi culture, to othering and a differentiation between 'us' and 'them' (Coupland, 2010). Moreover, it might contribute to erasure of diversity within Sámi culture (see Irvine \& Gal, 2000). Here it is relevant to note that we did not see traces of the Kven/Norwegian Finns. This absence could either be due to short-term presence of this national minority in the daily activities to the extent that we as researchers did not capture it, or it could be due to a pedagogical and semiotic negligence and 
erasure of this group. Also, the national minorities in Norway were not emphasized in the 2011 framework plan.

Regarding the Sámi beaska in Figure 9, the head of Mountain Kindergarten stated they received the coats as a gift, and since they did not know where to place them, they were temporarily placed in the hallway close to the teachers' wardrobe:

And so they were hanging there a bit because we think it was nice to get them and we had not found a specific place for them. [...] And then we had a girl doing practical training. She was around 19 [years old]. And one day, she suddenly comes to me and says, 'when we have the Sámi day, I can put them on, I see they are hanging there, I can put on a kofte that I have sewn. And then I can come an extra day that day and tell a bit or be with you during circle time'. And I told her that would be great [...]. And she was Sámi, you know. And I thought that maybe this made her develop the idea, because she saw something from her culture (Head of Mountain Kindergarten, our translation).

The coats were rarely visible to the children because the hallway was a part of the kindergarten that was not accessible to them. The interview indicated that the placement of the coats was preliminary and coincidental, and was not an integrated part of the kindergarten's practice. Nevertheless, the coats led to social action; a student voluntarily contributed to the celebration of the Sámi National Day. The head of kindergarten interpreted the coats as items from the student's culture, which may position them as items that differ from the kindergarten's culture (Bakhtin, 1986), leading to othering (Coupland, 2010). Still, they can be viewed as an utterance (Bakhtin, 1986) that led to another utterance at a later point in time (i.e. the student's social action). Her action can be interpreted as an utterance of the integration and positioning of Sámi culture within the kindergarten. In using the clothes for pedagogical purposes, the student changes the affordances of the coats as semiotic resources. Drawing upon Irvine and Gal (2000), the use of the clothes changes the indexical links between Sámi culture and the kindergarten and, hence, the conceptualisation of belonging in relation to Sámi culture. However, it is uncertain whether the engagement with Sámi culture lasted for longer than the celebration on the national day.

A question that arises from our analysis is how the exotic and the ordinary can be balanced when working with diversity in kindergarten. This balance was addressed in an interview:

The most important thing for us is that, when people come inside, that they are supposed to see a bit that we are the kindergarten we are. But we have worked a bit on that, [so] there should be a balance. It should not be so incredibly exotic, but it should be an ordinary kindergarten. But our target group should see it [linguistic and cultural diversity] at once. So, it [the semiotic landscape] is adjusted. 
But we have worked differently, little by little, so now we have just had a period of time where we have taken everything off the walls and thought about what we actually want to have there. Because it became so very, it became almost like a museum. It was so, oh so multicultural, and that was a bit too much. But it should show that is important for us; we wish to show that we also are an ordinary kindergarten. So, it is both (Kindergarten teacher, Mountain Kindergarten, our translation).

The kindergarten teacher presents a critical stance on the practices that the kindergarten has applied over time. We interpret her emic perspective as a view of the kindergarten staff as a part of the diversity of the kindergarten. The kindergarten staff understands their multiple cultural affiliations and cultural differences, such as during an intercultural encounter (see Barret et al., 2014) with the other cultures represented in the kindergarten group. From this perspective, Mountain Kindergarten has developed its visualisation practice beyond representing diversity through visual resources and in the direction of an intercultural encounter. This kindergarten shows that a balance in practices is an action that creates a sense of belonging for all involved parties and utilises a dialogical community (Østberg, 2017). Furthermore, the practices of the kindergarten may be read as an ongoing encounter of different ideologies (Freedman \& Ball, 2004), and this may also be an important element in the distinction between being 'ordinary' and 'exotic' and the teacher's reference to too much multiculturalism. From a critical research perspective, this may read as a process of erasure (Irvine \& Gal, 2000) of diversity towards becoming an ordinary and mainly Norwegian kindergarten. For us as researchers, this raises the question of what an ordinary Norwegian kindergarten may be and how this relates to the ideological struggle inherent in the tension to being 'exotic'.

\section{Discussion}

According to policy documents regulating everyday practices, the overarching goal of kindergartens is to ensure that all children's need for care and development are met, independent of their linguistic and cultural background. In addition, kindergartens aim to create a sense of belonging so that children thrive and take part in social and pedagogical practices. As we have shown in the analysis, kindergartens are physical places invested in historical, current, and future social, cultural, pedagogical, and political dialogues. The kindergartens we examined have semiotic landscapes in which linguistic and cultural diversity are shared values and create a place of belonging for all children. At the same time, the semiotic landscape includes resources that are obviously only for children with a migrant 
background, pointing to language and cultural diversity as an individual value that creates otherness (Bakhtin, 1986; Coupland, 2010). Furthermore, there are dialogical links to an official political discourse on the place of Sámi in kindergartens in addition to the local diversity represented by the kindergarten children and their families.

There are instances in which diversity is seen as exotic and put on display with little intention of integrating it into pedagogical practices. Moreover, the collective view that 'we who know Norwegian' is given more power than 'they, the learners of Norwegian'. This creates a hierarchical order, as 'we' have the knowledge that 'they' need to acquire. The 'we' position is naturalised and taken for granted in our data, as emphasised by the Russian-Norwegian booklet and the conflict-solving plan in Moon Kindergarten. This highlights a process of othering (Coupland, 2010) or group-based differentiation of the children involved in this semiotic landscape. Although the intentions and ideas revolve around inclusion and involvement, the staff see the document primarily as a resource for the Norwegian children, while multilingual children can look at the pictures. The kindergarten teachers' reflexivity signals an emerging dialogic approach between the inclusive ordinary and the exclusive exotic and between 'we' and 'they' in the semiotic landscape. However, this distinction also points to ideological struggles that relate to dichotomies in policy documents on whether this is true or tolerated diversity (Bubikova-Moan, 2017).

Our data only contains reported practices of cooperation with transnational parents by the teachers. As described in the analysis, these point to different expectations between parents and teachers regarding the display of flags. While the teachers understand the parents' reaction as positive, this may also relate to how parents and kindergarten teachers view each other's competence and influence in the kindergarten. Kindergarten teachers do not necessarily view parents as competent to contribute to the kindergarten practices, (Kultti \& Samuelsson, 2016), and a difference in power and knowledge is regarded as general challenge for equal collaboration with parents (Alasuutari, 2010; Einarsdottir \& Jonsdottir, 2018). This may also prevent parents from getting involved or even criticising the teachers.

There seems to be a difference with respect to how the kindergarten staff work with new and historical diversity, represented by recent transnational migrants to Norway and the Indigenous Sámi people. New diversity seems to be easier to address and more concrete, as there is a specific goal to support the acquisition of Norwegian. When it comes to Sámi, the staff seem to rely on more superficial pedagogical solutions in which culture and language are homogenised (Coupland, 2010) and stereotypically represented in the kindergartens. This might reflect a position of cultural hegemony. Also, according to our data, none 
of the children or teachers in either of the kindergartens considered themselves to be Sámi, and this might contribute to the officialness and less integrated local status of representations of Sámi in our data. Furthermore, we know that one long-term consequence of colonisation is lack of knowledge and relationship with Sámi language and culture. As Sámi is becoming more centred in the education sector, there might be an insecurity among non-Sámi kindergarten staff, whether they have both enough knowledge and legitimacy to talk about Sámi topics. A reason for this might be that according to our data, none of the children or teachers in either of the kindergartens considered themselves to be Sámi. The goal seems therefore to be to help children to differentiate between Sámi and Norwegian and not necessarily to acknowledge Sámi culture as part of being Norwegian. This observation reflects the ongoing process of rebalancing the relationships between the Sámi and Norwegian cultures in educational settings in Norway (Olsen \& Andreassen, 2016; Sollid \& Olsen, 2019). The goal of the process of Norwegianisation was to assimilate Sámi into Norwegian, giving little or no space to Sámi culture and language in everyday life at schools. The distribution of kindergartens across Norway emerged in the wake of the assimilatory politics during the 1970 s and alongside the emergence of explicitly emancipatory politics, as are evident in the latest Official Norwegian Report on the Sámi languages, Hjertespråket ('The language of the heart') (NOU 2016:18). One of the historical trajectories of the diversity discourse in Norwegian kindergartens and schools (Sollid, 2019) has been to promote Norwegian language, culture, and values, regardless of the children's background, as a way to develop equity. Recent framework plans, including the new kindergarten plan and also the school curriculum that entered into force in 2017, have increasingly emphasised the presence of education for and about Sámi (Olsen \& Andreassen, 2016; Sollid \& Olsen, 2019).

As researchers we are part of the Northern Norwegian diversity, and at times it seems like a long distance between our views and experiences on the one hand and the diversity discourses promoted through the semiotic landscapes of the kindergartens on the other. From an etic and critical perspective, one could emphasise the traces of othering and stereotypical representations of language and culture in the kindergartens as epistemically insurmountable. Rather, we acknowledge that developing an intercultural stance in kindergartens (Barret et al., 2014; Østberg, 2017) and ensuring that many voices in kindergartens are given space is part of an ongoing, long-term dialogue. In this dialogue, past, present, and future ideas of diversity and belonging frame the contemporary dialogues of kindergartens. Our data shows traces of dialogues and discourses on different time scales (Hult, 2017; Scollon \& Scollon, 2004). The relationship between guidelines in the policy documents and concrete practices in the kindergartens is an example of a dialogue with a long time scale, while the involvement 
of parents in the kindergarten's choice of flags and languages on the welcome poster is an example of a dialogue with a shorter time scale. Furthermore, these time scales intersect in chronotopes (Bakhtin, 1981) that are created in the semiotic landscape of the kindergartens, contributing to both belonging and othering.

\section{Conclusion}

In this article we have analysed the semiotic landscapes of two Norwegian kindergartens. The analysis reveals some tensions within discourses of diversity and belonging. One tension concerns practices that create space for belonging on the one hand and practices that create differences on the other. The semiotic landscapes ensure belonging for all children and include diversity as a shared value, and at the same time diversity is an individual value which single or groups of children and their families differently within the same space. Another tension exists between the ordinary and the exotic. On the one hand we find a discourse about the linguistically and culturally diverse kindergarten as a place like every other Norwegian kindergarten. On the other hand, the display of the diversity of the children and families involved with the kindergarten, may result in differences compared to other - ordinary - kindergartens. The ordinary is connected to pedagogical practices in everyday dialogues with children, while the exotic involves putting semiotic resources on display, sometimes in a similar way to a museum, as expressed by the teacher from Mountain Kindergarten. In our study, the connections between the pedagogical practices and the semiotic resources also link to a third tension related to practices concerning historical minorities. As pointed out, historical minorities are represented by stereotypical cultural artefacts, homogenising Sámi culture and languages and erasing diversity. Moreover, due to historical processes the Indigenous Sámi seem to be less integrated in daily pedagogical practices than transnational migrants. National minorities are not represented in the semiotic landscape. More research should focus on how historical minorities can be an integral part of Norwegian kindergartens, as required by the framework plan. Moreover, the discursive connections between Sámi, multilingual and Norwegian children are unclear in policy documents and involve different, contradictory ideologies when it comes to language and cultural revitalisation and reclamation. These different forms of diversity intersect in institutional reality, meaning that there is a need for more research both on how historical minorities can be an integral part of Norwegian kindergartens and on encounters between historical minorities and transnational migrants in educational institutions. 


\section{Acknowledgements}

We would like to thank Florian Hiss and two anonymous peer reviewers for their critical and constructive comments. Any shortcomings or errors are entirely our own.

\section{References}

Alasuutari, M. (2010). Striving at partnership: Parent-practitioner relationships in Finnish early educators' talk. European Early Childhood Education Research Journal, 18(2), 149-161. https://doi.org/10.1080/13502931003784545

Bakhtin, M. M. (1981). The Dialogic Imagination. Four Essays by M. M. Bakhtin (C. Emerson \& M. Holquist, Transl.). Austin, Texas: The University of Texas Press.

Bakhtin, M.M. (1986). Speech Genres and Other Late Essays (V.W. McGee, Trans., C. Emerson \& M. Holquist, Eds.). Austin, TX: University of Texas Press.

Barnehageloven. (2005). Lov om barnehager m.v. av 1. januar $2006 \mathrm{nr}$. 64. Retrieved from https://lovdata.no/dokument/NL/lov/2005-06-17-64

Barret, M., Byram Lázár, I., Mompoint-Gaillard, P., \& Philippou, S. (2014). Developing Intercultural Competence Through Education. Strasbourg: Council of Europe Publishing.

Blackledge, A., \& Creese, A. (2010). Multilingualism: A Critical Perspective. London \& New York: Continuum International Publishing Group.

Blommaert, J. (2013). Ethnography, Superdiversity and Linguistic Landscapes: Chronicles of Complexity. Bristol, Ontario: Multilingual Matters. https://doi.org/10.21832/9781783090419

Brochmann, G. \& Kjeldstadli, K. (2014). Innvandringen til Norge 900 - 2010. Oslo: Pax Forlag. Brown, K.D. (2012). The linguistic landscape of educational spaces: Language revitalization and schools in Southeastern Estonia. In D. Gorter, H.F. Marten, \& L. Van Mensel (Eds.), Minority Languages in the Linguistic Landscape (pp. 281-298). Retrieved from http://link .springer.com/chapter/10.1057/9780230360235_16. https://doi.org/10.1057/9780230360235_16

Bubikova-Moan, J. (2017). Constructing the multilingual child: The case of language education policy in Norway. Critical Discourse Studies, 14(1), 56-72. https://doi.org/10.1080/17405904.2016.1190389

Coupland, N. (2010). 'Other' representation. In J. Jaspers, J.-O. Östman, \& J. Verschueren (Eds.), Society and Language Use (pp. 241-260). Amsterdam: John Benjamins Publishing Company. https://doi.org/10.1075/hoph.7.16cou

De Vocht, L. (2015). Reconceptualizing Teacher-Child Dialogue in Early Years Education: A Bakhtinian Approach. (PhD Dissertation, University of Canterbury/New Zealand). Retrieved from https://ir.canterbury.ac.nz/handle/10092/10936

Einarsdottir, J., \& Jonsdottir, A.H. (2018). Parental engagement in Icelandic preschools. In E. E. Ødegaard \& S. Garvis (reds.), Nordic Dialogues on Children and Families (pp. 143-156). Abingdon, Oxon \& New York: Routledge.

European Council Communication. (2011). Early Childhood Education and Care: Providing all Our Children with the Best Start for the World of Tomorrow. Retrieved from https://eurlex.europa.eu/LexUriServ/LexUriServ.do?uri=COM:2011:0066:FIN:EN:PDF 
Freedman, S.W., \& Ball, A.F. (2004). Bakhtinian concepts to guide the study of language, literacy, and learning. In A.F. Ball \& S.W. Freedman (Eds.), Bakhtinian Perspectives on Language, Literacy and Learning (pp. 3-33). Cambridge, UK: Cambridge University Press. https://doi.org/10.1017/CBO9780511755002.001

Garvin, R.T. (2010). Responses to the linguistic landscape in Memphis, Tennessee: An urban space in transition. In E. Shohamy, E. Ben-Rafael, \& M. Barni (Eds.), Linguistic Landscape in the City (pp. 252-271). Bristol, UK: Multilingual Matters. https://doi.org/10.21832/9781847692993-016

Garvin, R.T., \& Eisenhower, K. (2017). A comparative study of linguistic landscapes in middle schools in Korea and Texas: Contrasting signs of learning and identity construction. In R. Blackwood, E. Lanza, \& H. Woldemariam (Eds.), Negotiating and Contesting Identities in Linguistic Landscapes (pp. 215-231). London, New York: Bloomsbury.

Gorter, D. (2006). Introduction: The study of the linguistic landscape as a new approach to multilingualism. International Journal of Multilingualism, 3(1), 1-6. https://doi.org/10.1080/14790710608668382

Hult, F. M. (2017). Nexus analysis as scalar ethnography for educational linguistics. In M. Martin-Jones \& D. Martin (Eds.), Researching Multilingualism: Critical and Ethnographic Perspectives (pp. 89-104). London \& New York: Routledge.

Irvine, J. (1989). When talk isn't cheap: Language and political economy. American Ethnologist, 16(2), 248-267. https://doi.org/10.1525/ae.1989.16.2.02a00040

Irvine, J. T., \& Gal, S. (2000). Language ideology and linguistic differentiation. In P.V. Kroskrity (Ed.), Regimes of Language: Ideologies, Polities, and Identities (pp. 35-83). Santa Fe, NM: School of American Research Press.

Jaworski, A., \& Thurlow, C. (2010). Introducing semiotic landscapes. In A. Jaworski \& C. Thurlow (Eds.), Semiotic Landscapes: Language, Image, Space (pp. 1-40). London, New York: Continuum International Publishing Group.

Karpov, Y.V. (2005). The Neo-Vygotskian Approach to Child Development. Cambridge, UK: Cambridge University Press. https://doi.org/10.1017/CBO9781316036532

Kommuneprofilen. (2019). Innvandrerbefolkningen. Retrieved from https://www .kommuneprofilen.no/Profil/Kommunefakta/Innvandrere_kommune.aspx

Kunnskapsdepartementet. (2011). Rammeplan for barnehagens innhold og oppgaver. Bergen: Fagbokforlaget.

Kvale, S., \& Brinkmann, S. (2017). Det kvalitative forskningsintervju (3rd ed.). Oslo: Gyldendal Akademisk Forlag.

Kultti, A. \& Samuelsson, I.P. (2016). Diversity in initial encounters between children, parents and educators in early childhood education. In K. Fischer, I. Kaschfi-Haude \& J. Schneider (Eds.), Voices on Participation: Strenghtening Activity-oriented Interactions and Growth in The Early Years and in Transitions: SIGNALS, EU Lifelong Learning Program, 140-152. Retrieved from http://www.signals-eu.com/

Laihonen, P., \& Szabó, T. P. (2017). Investigating visual practices in educational settings. Schoolscapes, language ideologies and organizational cultures. In M. Martin-Jones \& D. Martin (Eds.), Researching Multilingualism: Critical and Ethnographic Perspectives (pp. 121-138). Abingdon, Oxon, \& New York: Routledge.

Laihonen, P., \& Szabó, T. P. (2018). Studying the visual and material dimensions of education and learning. Linguistics and Education 44, 1-3. https://doi.org/10.1016/j.linged.2017.10.003 
Laihonen, P., \& Tódor, E.M. (2015). The changing schoolscape in a Szekler village in Romania: Signs of diversity in rehungarization. International Journal of Bilingual Education and Bilingualism, 20(2), 362-379. https://doi.org/10.1080/13670050.2015.1051943

Lødding, B. (2015). Mobilisering for mangfold: Kartlegging av kompetanse i barnehagesektor og grunnoplaring for barn, unge og voksne i forste fase av satsingen Kompetanse for mangfold. Retrieved from https://nifu.brage.unit.no/nifu-xmlui/handle/11250/281882

Norwegian Directorate for Education and Training. (2017). Framework Plan for Kindergartens: Contents and Tasks. Retrieved from https://www.udir.no/globalassets/filer /barnehage/rammeplan/framework-plan-for-kindergartens2-2017.pdf

NOU 2016: 18. (2016). Hjertespråket: Forslag til lovverk, ordninger og tiltak for samiske språk. Retrieved from https://www.regjeringen.no/no/dokumenter/nou-2016-18/id2515222/?ch $=1$

Olsen, T.A., \& Andreassen, B.-O. (2016). Urfolk, forpliktelse og Ansvar. Urfolk og samiske fohold i barnehagens rammeplaner. In N. Askelad \& B. Aamotsbakken (Eds.), Folk uten lad? Å gi stemme og status til urfolk og nasjonale minoriteter (pp. 60-76). Kristiansand: Poartal.

Ongstad, S. (2004). Bakhtin's triadic epistemology and ideologies of dialogism. In F. Bostad, C. Brandist, L.S. Evensen, \& H.C. Faber (Eds.), Bakhtinian Perspectives on Language and Culture: Meaning in Language, Art and New Media (pp. 65-88). New York: Palgrave Macmillan. https://doi.org/10.1057/9780230005679_4

Pachné Heltai, B., \& Bartha, C. (2017). Ideologies and practices in a kindergarten offering early education in Northern Sámi outside the Sámi homeland. Apples - Journal of Applied Language Studies, 11(3), 7-28. https://doi.org/10.17011/apples/urn.201712104582

Pakarinen, S., \& Björklund, S. (2017). Multiple language signage in linguistic landscapes and students' language practices: A case study from a language immersion setting. Linguistics and Education, 44, 4-11. https://doi.org/10.1016/j.linged.2017.10.005

Pesch, A.M. (2017). Å skape rom for flerspråklighet: En studie av diskursive vilkår for barnehagens språklige praksis med flerspråklige barn (PhD). UiT Norges arktiske universitet, Tromsø.

Pietikäinen, S. (2014). Spatial interaction in Sámiland: Regulative and transitory chronotopes in the dynamic multilingual landscape of an indigenous Sámi village. International Journal of Bilingualism 18(5), 478-490. https://doi.org/10.1177/1367006913484210

Pietikäinen, S., Huss, L., Laihiala-Kankainen, S., Aikio-Puoskari, U. \& Lane, P. (2010). Regulating Multilingualism in the North Calotte: The Case of Kven, Meänkieli and Sámi Languages. Acta Borealia 27 (1), 1-23. https://doi.org/10.1080/08003831.2010.486923

Sadownik, A. (2018). Belonging and participation at stake: Polish migrant children about (mis)recognition of their needs in Norwegian ECECs. European Early Childhood Education Research Journal, 26(6), 956-971. https://doi.org/10.1080/1350293X.2018.1533711

Scollon, R., \& Scollon, S. W. (2004). Nexus Analysis: Discourse and the Emerging Internet. New York: Routledge. https://doi.org/10.4324/9780203694343

Silseth, K. (2014). Dialogisme som tilnærming til læring. In J.H. Stray \& L. Wittek (Eds.), Pedagogikk. En grunnbok (pp. 149-161). Oslo: Cappelen Damm.

Sollid, H. (2019). Språklig mangfold som språkpolitikk i klasserommet. Målbryting, 10, 1-21. https://doi.org/10.7557/17.4807

Sollid, H., \& Olsen, T.A. (2019). Indigenising education: Scales, interfaces and acts of citizenship in Sápmi. Junctures, 20. https://doi.org/10.34074/junc.20 
Statistics Norway. (2020a). Innvandrere og norskfødte med innvandrerforeldre. Retrieved from https://www.ssb.no/innvbef

Statistics Norway. (2020b). Kindergartens, 2019, final numbers. Retrieved from https://www.ssb .no/en/utdanning/statistikker/barnehager/aar-endelige

Szabó, T.P. (2015). The management of diversity in schoolscapes: An analysis of Hungarian practices. Apples - Journal of Applied Language Studies, 9(1), 23-51. https://doi.org/10.17011/apples/2015090102

Szabó, T.P., \& Troyer, R.A. (2017). Beyond the binaries of the observer and observed in linguistic landscape studies. Linguistic Landscape, 3(3), 306-326. Retrieved from http:// www.jbe-platform.com/content/journals/10.1075/11.17008.sza

Tønnesen, E.S. (2010). Tekstpraksis i bevegelse. In E.S. Tønnesen (Ed.), Sammensatte tekster: barns tekstpraksis (pp. 10-22). Oslo: Universitetsforlaget.

Utdanningsdirektoratet. (2017, 13.1.2017). Kompetanse for mangfold. Retrieved from https:// www.udir.no/tall-og-forskning/finn-forskning/rapporter/kompetanse-for-mangfold/

Vertovek, S. (2007). Super-diversity and its implications. Ethnic and Racial Studies, 30(6), 1024-1054. https://doi.org/10.1080/01419870701599465

Vygotsky, L. (1986). Thought and Language (A. Kozulin, Trans., A. Kozulin Ed.). Cambridge, MA, \& London, UK: The MIT Press.

Wittek, L. (2014). Arven fra Vygotsky. In J.H. Stray \& L. Wittek (Eds.), Pedagogikk: En grunnbok (pp. 286-300). Oslo: Cappelen Damm.

Øierud, G.L. (2011). Hvordan analysere multimodalitet? In T. R. Hitching, A. B. Nilsen, \& A. Veum (Eds.), Diskursanalyse i praksis: metode og analyse (pp. 43-48). Kristiansand: Høyskoleforlaget.

Østberg, S. (2017). Interkulturell kompetanse. In V. Bjarnø, M.E. Nergård, \& F. Aarsæther (Eds.), Språklig mangfold og loering: Didaktikk for flerspråklige klasserom. (pp. 17-35).

Oslo: Gyldendal Norsk Forlag.

Øzerk, K. (2016). Tospråklig oppvekst og loering. Oslo: Cappelen Damm Akademisk.

\section{Sammendrag}

Utdanningsinstitusjoner har et ansvar for å sikre at alle barn får omsorg og like muligheter for utvikling, uavhengig av språklig og kulturell bakgrunn. Det er likevel lite kunnskap om hvordan barnehager arbeider for å være et sted der både barn med transnasjonal minoritetsbakgrunn, barn med urfolksbakgrunn og barn fra majoritetsbefolkningen får en opplevelse av å være velkommen og høre til. Gjennom en semiotisk landskapsanalyse av to barnehager i NordNorge bidrar denne artikkelen til kunnskap på dette feltet. Vårt utgangspunkt er at utdanningsinstitusjoner er sosiale, kulturelle og politiske steder. Basert på bakhtinske perspektiv der vi ser på semiotiske landskap som dialoger, fokuserer analysen på to diskurser. Den første omhandler mangfold som individuell eller felles verdi, og den andre omhandler balansen mellom det ordinære og det eksotiske. Våre funn viser at mangfold som er knyttet til transnasjonal migrasjon, virker å være integrert i større grad i de semiotiske landskapene i barnehagene, mens samene er framstilt gjennom stereotypiske representasjoner. 


\title{
Address for correspondence
}

\author{
Anja Maria Pesch \\ Department of Social and Educational Sciences \\ Inland Norway University of Applied Sciences \\ P.O. Box 400 \\ $\mathrm{N}-2418$ Elverum \\ Norway \\ anja.pesch@inn.no
}

\section{Co-author information}

\author{
Maria Dardanou \\ Department of Education \\ UiT The Arctic University of Norway \\ maria.dardanou@uit.no
}

\section{Publication history}

Date received: 1 September 2020

Date accepted: 29 March 2021

Published online: 20 April 2021
Hilde Sollid

Department of Language and Culture UiT The Arctic University of Norway

hilde.sollid@uit.no 